Review

\title{
Targeting TNF and TNF Receptor Pathway in HIV-1 Infection: from Immune Activation to Viral Reservoirs
}

\author{
Sébastien Pasquereau, Amit Kumar and Georges Herbein * \\ Department of Virology, University of Franche-Comte, University of Bourgogne-Franche-Comté (UBFC), \\ CHRU Besançon, UPRES EA4266 Pathogens \& Inflammation/EPILAB, SFR FED 4234, F-25030 Besançon, France; \\ sebastien.pasquereau@univ-fcomte.fr (S.P.); amit.aiims2005@gmail.com (A.K.) \\ * Correspondence: georges.herbein@univ-fcomte.fr; Tel.: +33-370-632-512 \\ Academic Editor: Jens H. Kuhn
}

Received: 31 January 2017; Accepted: 23 March 2017; Published: 30 March 2017

\begin{abstract}
Several cellular functions such as apoptosis, cellular proliferation, inflammation, and immune regulation involve the tumor necrosis factor- $\alpha$ (TNF)/TNF receptor (TNFR) pathway. Human immunodeficiency virus 1 (HIV-1) interacts with the TNF/TNFR pathway. The activation of the TNF/TNFR pathway impacts HIV-1 replication, and the TNF/TNFR pathway is the target of HIV-1 proteins. A hallmark of HIV-1 infection is immune activation and inflammation with increased levels of TNF in the plasma and the tissues. Therefore, the control of the TNF/TNFR pathway by new therapeutic approaches could participate in the control of immune activation and impact both viral replication and viral persistence. In this review, we will describe the intricate interplay between HIV-1 proteins and TNF/TNFR signaling and how TNF/TNFR activation modulates HIV-1 replication and discuss new therapeutic approaches, especially anti-TNF therapy, that could control this pathway and ultimately favor the clearance of infected cells to cure HIV-infected patients.
\end{abstract}

Keywords: TNF; TNF receptor; HIV-1; reservoirs; immune activation; anti-TNF therapy

\section{Introduction}

Tumor necrosis factor- $\alpha$ (TNF) was first described as a glycoprotein induced in response to endotoxin (the old name of which was cachectin) and has the capacity to kill tumor cells [1]. Then, TNF was shown to be a T helper type 1 (Th1) cytokine produced by several cell types, including monocytes/macrophages and T-cells, and to be involved in proinflammatory responses like interleukin (IL)-1 $\beta$ and IL-6 [2]. TNF exerts its effects by binding as a trimer to two cell membrane TNF receptors (TNFRs), TNFR1 (55-kDa) and TNFR2 (75 kDa) [2]. In concert with chemokines, TNF and TNFRs are involved in the regulation of inflammatory processes like arthritis, of infectious diseases including HIV infection, and of malignancies, since chronic inflammation has been recognized to play a major role in carcinogenesis [3-5].TNF was first recognized at the protein level, followed by identification of its cDNA sequence $[4,6,7]$. TNFRs are composed of an extracellular domain common to all TNFR superfamily members, a typical cysteine rich motif, and intracellular domains with distinct motifs, allowing the accomplishment of various intracellular functions $[8,9]$. Death receptors are members of the TNFR superfamily characterized by a cytoplasmic region, the death domain, that enables the receptors to trigger pro-death signals within the cell [4]. TNFR1 possesses a death domain, and TNFR2 lacks one. This allows TNF to deliver distinct intracellular signals after binding to its receptors. We will discuss in this review how the binding of TNF to its receptors modulates the cellular activation, the interaction between human immunodeficiency virus 1 (HIV-1) proteins, and TNF/TNFR signaling, and the role of TNF/TNFRs in the modulation of the viral life cycle. In addition, we will address the 
impact of the TNF/TNFR pathway on the immune activation and the formation of viral reservoirs during the course of HIV-1 infection. The opportunity to modulate the TNF effect and the TNFR pathway by anti-TNF therapy and/or to stimulate viral reactivation by TNF or TNF inducers to purge the HIV-1 reservoir will be discussed.

\section{TNF/TNFR Signaling}

Many cell types, especially immune cells, produce TNF in response to pathological conditions such as inflammation and infection, including: activated macrophages and T lymphocytes, natural killer (NK) cells, mast cells, and fibroblasts [4,8]. A membrane protein belonging to the ADAM (a disintegrin and metalloproteinase) family, the TNF- $\alpha$ converting enzyme (TACE) cleaves various membrane proteins including the TNF precursor, a $25 \mathrm{kDa}$ plasma bound protein, into a $17 \mathrm{kDa}$ soluble TNF form [10]. In their trimeric configuration, both membrane-bound and soluble TNF forms are functional when binding to their receptors. Although both TNF forms can bind to each of the two receptors, they display a dichotomic effect. The plasma membrane associated with $25 \mathrm{kDa}$ TNF binds preferentially to the TNFR2, whereas the soluble $17 \mathrm{kDa}$ TNF interacts with TNFR1 with high specificity [11,12]. Several intracellular pathways are triggered by TNF binding to its receptors, including the modulation of the apoptotic pathway, NF-kB stimulation, and the activation of p38 mitogen-activated protein kinases (MAPK), extracellular signal-regulated kinase (ERK), and c-Jun N-terminal kinase (JNK) $[4,8]$ (Figure 1).

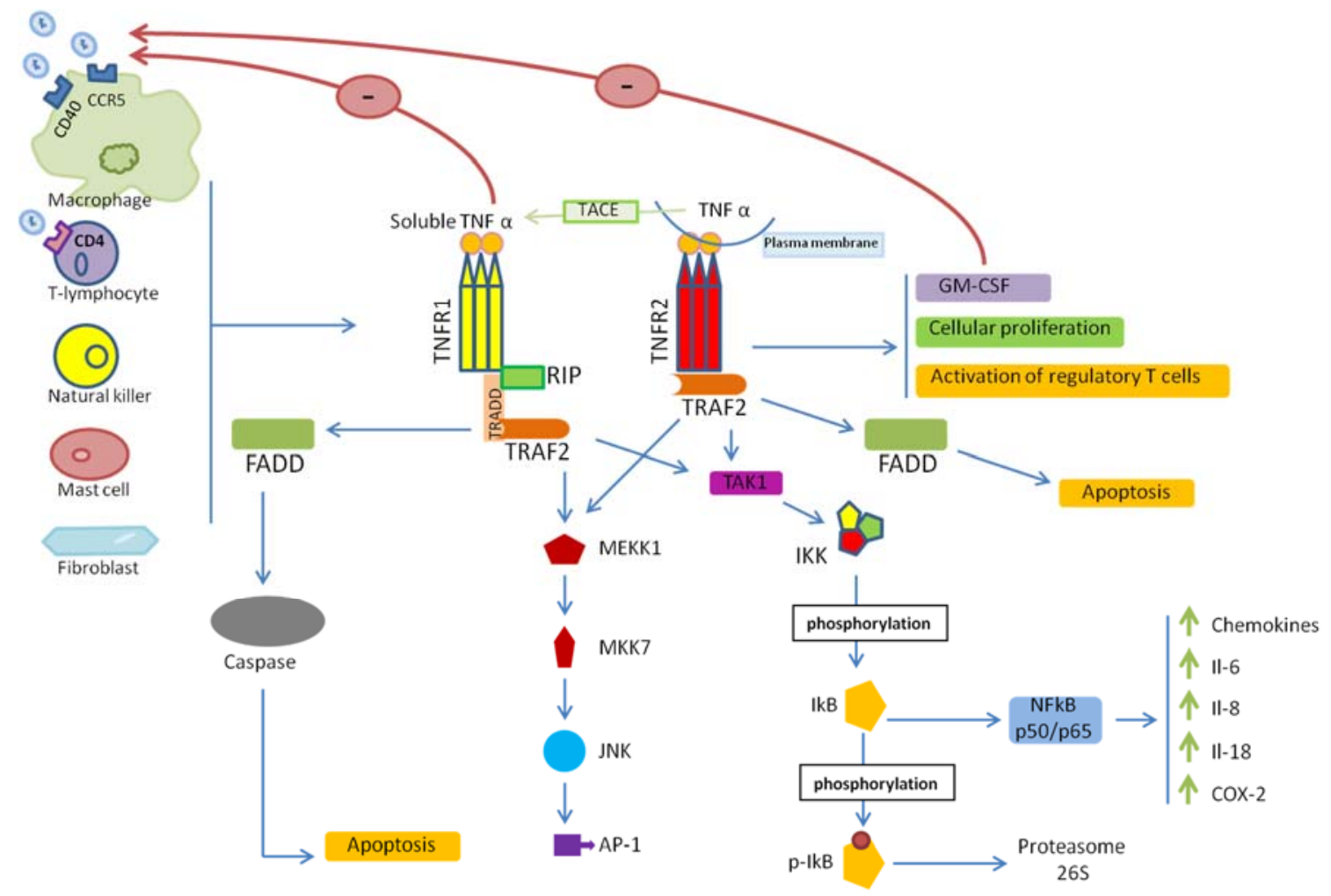

Figure 1. Tumor necrosis factor- $\alpha$ (TNF)/TNF receptor (TNFR)-mediated cell signaling. The binding of TNF to TNFRs leads to the recruitment of adaptor proteins-TNFR-associated death domain (TRADD), Fas-Associated death domain (FADD), TNF receptor associated factor (TRAF), and receptor interacting protein (RIP) - that activates several signaling cascades leading to the activation of transcription factors (NF- $\mathrm{kB}, \mathrm{AP}-1$ among others) and/or caspase cascades. COX-2: cyclooxygenase-2; FADD: Fas-associated death domain; GM-CSF: Granulocyte-macrophage colony-stimulating factor; IкB: NF-кB inhibitor;

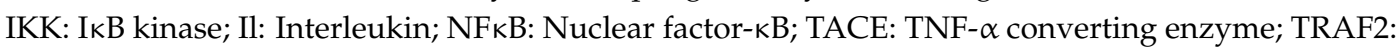
TNFR-associated factor 2; TRADD: TNFR-associated death domain. 
A $34 \mathrm{kDa}$ adapter protein called TNFR-associated death domain (TRADD) interacts with the cytoplasmic death domain of TNFR1 through its own death domain in response to the binding of TNF to TNFR1 [13] (Figure 1). Further, a Fas-Associated death domain protein (FADD) binds to TRADD and activates apoptosis via the caspase cascade [14] (Figure 1). On the other hand, the sequential recruitment of receptor interacting protein (RIP), transforming growth factor (TGF)- $\beta$-activated kinase 1 (TAK1), and IKB kinase (IKK) by the TNF receptor associated factor 2 (TRAF2) forms a complex that interacts with TRADD $[8,15,16]$. The phosphorylation of IKB by IKK and its subsequent degradation in the proteasome leads to NF- $\mathrm{KB}$ translocation into the nucleus, where it binds to the promoters of genes involved in inflammation, such as TNF, IL-6, IL-8, IL-18, chemokines, and cyclooxygenase-2 (COX-2) genes $[4,8,15,17]$ (Figure 1). In addition to stress and growth factors, cellular proliferation can be triggered by TNF binding to TNFR1, followed by activation of the following axis; TRADD, TRAF2-RIP, mitogen-activated protein kinase kinase kinase 1(MEKK1), mitogen-activated protein kinase kinase 7 (MKK7), and JNK, ultimately leading to the activation of the AP-1 transcription factor $[4,8,18]$ (Figure 1 ). Although TNFR2 lacks a death domain, it interacts with TRAF2 and can activate the transcription factors NF- $\mathrm{kB}$ and AP-1 (Figure 1). Cell proliferation and survival, activation of regulatory T-cells, and the induction of granulocyte-macrophage colony-stimulating factor (GM-CSF) secretion can be elicited through TNF/TNFR2 signaling [19-21].

\section{TNF/TNFRs and HIV-1 Entry}

The role of TNF in HIV-1 entry has been extensively described, especially in primary human macrophages (Figure 1) [22]. In vitro, the primary macrophages infected by HIV-1 or treated with HIV-1 envelope protein gp120 release TNF in culture supernatants [23]. A delayed detection of HIV DNA long terminal repeat (LTR) up to $72 \mathrm{~h}$ has been observed in macrophages pre-treated by TNF parallel to the downregulation of the CD4 receptor [22-26]. Therefore, one explanation for the inhibition of HIV entry into permissive cells by TNF might be the down regulation of the expression of the HIV CD4 receptor and the C-C chemokine receptor type 5 (CCR5) coreceptor on the cell surface [24]. In fact, CCR5 downregulation on the cell surface results from the secretion of GM-CSF following the stimulation of macrophages with TNF, which will ultimately result in the inhibition of the entry of CCR5-dependent HIV-1 strains [25]. In addition, the binding of TNF to TNFR2 activates NF- $\mathrm{kB}$ and favors enhanced secretion of HIV suppressive factors, such as macrophage inflammatory protein- $1 \alpha$ (MIP-1 $\alpha$ ), MIP-1 $\beta$, and regulated on activation, normal T-cell expressed and secreted (RANTES). These factors also downregulate CCR5 on the cell surface [27-31], indicating that the TNF inhibition of HIV entry is mediated through TNFR2 but not TNFR1. However, the inhibition of viral entry is not related to the CD4 downregulation in macrophages. Both surface and total CD4 are downregulated in macrophages at the level of transcription after TNF pretreatment for one to five days [23,24]. However, after TNF pretreatment for $2 \mathrm{~h}$, a $75 \%$ decrease in virus entry is observed, although the levels of surface CD4 expression are not yet modified. In addition, the surface CD4 downregulation in TNF-treated macrophages is mediated through TNFR1 but not through TNFR2 [22-24,26]. Therefore, the inhibition of HIV-1 entry into macrophages by TNF is mediated through the TNF-R2 but not through TNF-R1 and is independent of the modulation of surface CD4 expression. Altogether, the downregulation of the CCR5 co-receptor is the main mechanism that inhibits HIV entry into macrophages treated with TNF and is not related to the downregulation of the CD4 receptor. However, we cannot exclude that the inhibition of the HIV-1 entry into macrophages could also result from post-binding steps, which have still to be identified.

\section{TNF/TNFR Signaling in HIV-1 Infection}

Several intracellular signaling pathways, including NF- $\mathrm{kB}$, JNK, and p38 MAP kinase pathways, are triggered by TNF (Figure 1) [32]. Diverse cellular functions are regulated by the members of the p38 family, consisting of p38 $\alpha, \mathrm{p} 38 \beta, \mathrm{p} 38 \gamma$, and p38 , through the phosphorylation of transcription factors such as activator protein 1 (AP-1), activating transcription factor 2 (ATF-2), and cAMP response 
element binding protein(CREB) [33]. The first isoform discovered for its role in endotoxin-induced inflammatory response and osmotic shock is $\mathrm{p} 38 \alpha[33,34]$. Independent or synergistic activation of NF- $\mathrm{kB}$ and $\mathrm{p} 38$ by TNF can be observed $[35,36]$. Specific signaling pathways leading to the activation of either pro-survival mediators or effectors of cell death can be observed in response to TNF stimulation. By binding to TNFR, TNF activates NF- $\mathrm{kB}$, which promotes cell survival, JNKs, and caspases, which favor cell death. Therefore, an exquisite crosstalk between the two pathways will decide the cellular fate [37]. In addition, in HIV-1 infected cells, TNF stimulation will favor the binding of p65/p50 NF- $\mathrm{BB}$ and AP-1 complexes to their respective transcription factor binding sites present in the HIV-1 long terminal repeat (LTR) promoter. Thus, TNF-mediated translocation of NF- $\mathrm{KB}$ to the nucleus, followed by LTR stimulation, fuels HIV-1 production in chronically infected T-cell lines and promonocytic cell lines, such as the ACH2 and U1 cell lines, respectively [38-42]. Although TNF could be a major driver of HIV-1 transcription early in the disease, later on, during the progression of the disease, a T helper Th1/Th2 shift has been described [43]. Since Th2 cytokines are mostly immunosuppressive with decreased levels of TNF production at advanced stages of the disease, HIV-1 replication could be sustained by the production of some HIV proteins that mimic TNF activity. We and others reported previously that several HIV-1 proteins, especially viral protein $\mathrm{R}(\mathrm{Vpr})$, trans-activator of transcription (Tat), negative regulatory factor (Nef), and envelope glycoprotein gp120, activate signaling pathways that are also triggered by TNF, especially in macrophages (Reviewed in [44]) (Figure 2).

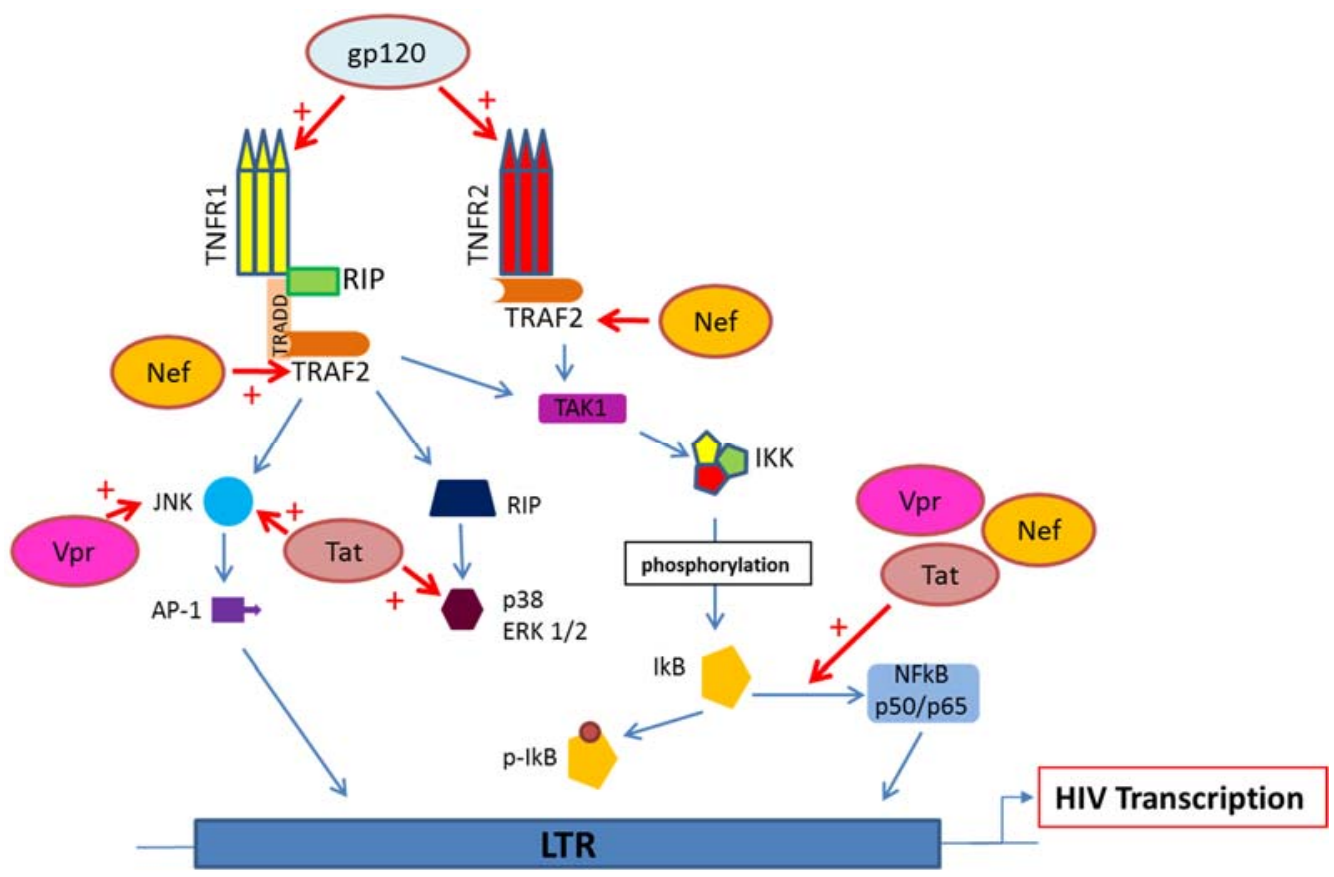

Figure 2. The TNF/TNFR pathway is targeted by human immunodeficiency virus 1 (HIV-1) proteins. HIV-1 proteins viral protein $\mathrm{R}(\mathrm{Vpr})$, trans-activator of transcription (Tat), negative regulatory factor (Nef), and envelope glycoprotein gp120 interfere with the TNF/TNFR pathway to enhance HIV transcription in infected cells.

\section{HIV Proteins Interaction with TNFR and Downstream Signaling Pathways}

Vpr encodes a 96-amino acid, $14 \mathrm{kDa}$ protein, which is conserved among HIV-1, HIV-2, and simian immunodeficiency virus. Multiple cellular functions are targeted by $\mathrm{Vpr}$, including the induction of cell cycle arrest in the G2 phase, transactivation of the LTR promoter, nuclear import of preintegration complexes, and modulation of apoptosis. Both pro- and anti-apoptotic roles of Vpr have been described. Vpr triggers apoptosis in infected T-cells through activation of caspases $3 / 7,8$, and $9[45,46]$ and by blocking NF-KB activation in myeloid cells [47]. In contrast, Vpr expression in the Jurkat cell line has 
been reported to enhance resistance to TNF-induced apoptosis [48]. In addition to these functions, Vpr triggers the mitochondrial dysfunction [49,50]. Vpr is critical for HIV replication in non-dividing cells, e.g., macrophages [44], but is not required for replication in T-cells. Like TNF, recombinant Vpr activates NF- $\mathrm{KB}, \mathrm{AP}-1$, and JNK in primary macrophages and monocytoid U937 cells, resulting in the stimulation of HIV-1 LTR and the subsequent enhancement of viral replication [44,51]. Vpr-dependent activation of NF- $\mathrm{kB}$ has also been reported in primary T-cells [52]. In addition, HIV production is increased by Vpr through toll-like receptor 4 (TLR4) and IL-6 secretion [50]. Recently, Vpr has been reported to enhance TNF production by HIV-1-infected T-cells, implicating the cellular proteins TAK1 and damage-specific DNA binding protein 1 (DDB1) in this phenomenon [53]. TNF produced by infected cells activates NF- $\mathrm{KB}$ in bystander cells and favors viral reactivation from the HIV-1 reservoir [53]. Also, enhanced stimulation of HIV-1 LTR results from a synergistic effect of Vpr and Tat [54]. A few reports indicate that in some cases Vpr can inhibit NF- $\mathrm{kB}$ activation. For example, the inhibition of NF- $\mathrm{kB}$ mediated gene expression results from a synergistic action of $\mathrm{Vpr}$ and glucocorticoid receptors via a pathway involving the suppressor of poly (ADP-ribose) polymerase (PARP)-1 nuclear trafficking in response to TNF $[47,55]$. Thus, the respective roles of Vpr and TNF on cellular functions and HIV-1 replication are complex and depend on the cell type involved.

A close interplay between TNF and HIV-1 Nef is present throughout the progression of the disease [56]. The multifunctional 27kDa myristoylated Nef protein triggers NF- $\mathrm{kB}$ activation in macrophages and monocytoid U937 cells, favoring the HIV LTR activation in vitro [57,58], and the transcription of several genes coding for proinflammatory cytokines and chemokines such as TNF, IL-6, MIP- $1 \alpha$, and MIP-1 $\beta$ [59-61]. The phosphorylation of several key-signaling molecules, including $\alpha / \beta$ subunits of IKB kinase, ERK1/2, JNK, and $\mathrm{p} 38$, is triggered in macrophages treated with recombinant Nef in vitro [60]. Moreover, Nef and TNF synergistically stimulate the HIV-1 replication in monocytic cells and primary macrophages [62], and Nef directly interacts with several TRAF proteins (TRAF2, TRAF5, TRAF6) to enhance the HIV-1 replication in macrophages [63]. In addition to a plasma membrane(PM)-associated TNF shedding, the secretion of vesicular TNF endosomes has been recently described as an alternative TNF secretion mechanism, where Nef-mediated routing of the TNF alpha-converting enzyme (TACE) ADAM17 into Rab4+ early endosomes and the Rab27+ secretory pathway leads to intracellular proTNF cleavage and secretion of vesicular TNF endosomes [64]. For the vesicular TNF endosomal trafficking of disintegrin and metalloproteinase domain-containing protein 17 (ADAM17), neurogenic locus notch homolog protein 1 (Notch1) is required [64]. In fact, in exosomes released from cells infected with viruses other than HIV, the presence of viral components has been reported including, among others, components of Epstein-Barr virus, cytomegalovirus, herpes simplex virus, and hepatitis $C$ virus [65]. Although the role of vesicular TNF has been less studied so far than its soluble TNF counterpart, T-cell activation, viral replication, and viral reactivation from HIV reservoir are enhanced by exosomes of HIV-1-infected cells through a Nef- and TNF-dependent mechanism [66,67]. In addition, exosomes from HIV-1-infected cells containing trans-activation response (TAR) RNA stimulate the production of TNF in primary macrophages [68]. Finally, exposure to Nef-containing exosomes released from transfected T-cell lines increases CD4+ T-cell apoptosis [57].

The HIV-1 Tat protein is critical for the elongation process during viral transcription, but also activates NF- $\mathrm{kB}$, JNK, p38, and ERK1/2 pathways and thereby could mimic the effect of TNF on cellular gene expression [44,69] (Figure 2). Both MyD88 and TIR-domain-containing adapter-inducing interferon- $\beta$ (TRIF) axes recruit the TLR4 pathway, following stimulation by Tat, and lead to the activation of protein kinase $\mathrm{C}$ beta2 isoform, MAP kinase, and NF- $\mathrm{kB}$, thus resulting in enhanced TNF production in monocytes [70].

The production of TNF, but also of IL-6, IL-10, and interferon $\gamma$, has been reported after the interaction of gp120 with CD4 (Reviewed in [71]). The production of TNF is triggered by gp120 in peripheral blood mononuclear cells isolated from HIV-1 infected patients [72-74], in macrophages treated with gp120 in vitro [75], and in animal models [76]. The PI3K and MAPK pathways are involved in the increase of TNF production, which is triggered by HIV gp120 [75,77]. In HIV-infected patients, 
a positive correlation between the levels of gp120 and the expression profiles of proinflammatory cytokines, including TNF, has been reported [78].

The interaction between macrophage-membrane bound TNF and TNFR2 present on CD8+ T-cells triggers CD8+ T-cell apoptosis [79]. Chronic inflammation in HIV-1 infection is characterized by the detection of soluble markers of immune activation, including, among others, neopterin, ß2 microglobulin, soluble CD30, TNF, and the soluble TNFR2 (sTNFR2) [80]. In symptomatic HIV-infected patients, increased TNF levels are detected in the serum, and elevated levels of sTNFR2 are predictive of disease progression [81].

\section{Anti-TNF Medications}

In several chronic inflammatory diseases, such as rheumatoid arthritis, ankylosing spondylitis, juvenile arthritis, psoriatic arthritis, Crohn's disease, and ulcerative colitis, the blockade of TNF signaling is commonly used. Thus, medications such as antibodies or receptors, which target the TNF/TNFR pathway for treating various inflammatory diseases, are now in preclinical or clinical phases of development [82,83]. In 1998, the human/murine chimeric antibody, infliximab, was approved. It binds with high affinity to both the soluble and the membrane-bound TNF. It was then followed by etanercept, a TNFR2-fragment cristallizable region $(\mathrm{Fc})$ fusion protein, that acts like a decoy to block TNF [84]. In 2002 and 2009, the fully human antibodies adalimumab and golimumab, which bind to TNF, were approved. Moreover, certolizumab pegol was approved in 2008. This anti-TNF monoclonal antibody contains a PEGylated Fab fragment, which targets TNF, with the advantage of being administrated to pregnant women. Thus, pregnant women with autoimmune diseases and in need of anti-TNF therapy can be treated with certolizumab pegol, since polyethylene glycol does not cross the placenta [85]. Additionally, the cells involved in inflammation could be lysed by adalimumab and infliximab, since both medications trigger apoptosis and cell cycle arrest in transmembrane TNF-expressing Jurkat T-cells. This could result in immune suppression, thus improving the course of inflammatory diseases, such as Crohn's disease, but with a risk of reactivation of latent tuberculosis in infected patients [82]. This negative effect can be prevented by appropriate screening, and HIV-infected patients should be adequately vaccinated when possible and closely monitored for early signs of infection. When serious infections occur, withdrawal of anti-TNF therapy may be necessary until the infection has been identified and properly treated.

\section{Anti-TNF Therapy and Control of Immune Activation in HIV-1 Infection}

At all stages of HIV-1 infection, increased amounts of TNF can be detected either in the plasma or in the tissues $[38,86,87]$. Even in combination antiretroviral therapy (cART) treated patients with undetectable viremia, immune activation is still present along with increased levels of plasma TNF [88-91]. In HIV-infected patients, the increased viral replication and depletion of CD4+ T-cells could result from enhanced TNF expression [92,93]. In addition, TNF impairs CD4+ T-cell-mediated immunological control in chronic viral infection [94]. Therefore, in addition to the inhibition of viral replication by cART, new therapeutic approaches, which control TNF production, could be helpful to curtail immune activation in HIV-infected patients. Thus, increased levels of TNF in HIV infection could be counteracted by anti-TNF therapy (Figure 3A).

Moreover, the release of soluble TNF receptors (sTNFR1 and sTNFR2), following the membrane-bound TNFR shedding by proteolytic cleavage, can compete with the membrane-bound TNFRs for binding to TNF, thus inhibiting its activity. In addition, the cells could be transiently desensitized to TNF action, due to the decrease in the number of membrane receptor molecules as a result of receptor shedding [95-97]. Nevertheless, to modulate HIV disease, TNF blocking agents and/or TNF inhibitor therapy could be useful, since HIV infection is characterized by immune activation and inflammation [98]. Several years ago the use of thalidomide, a TNF inhibitor, was suggested to reduce the serum TNF level and to control the viral load $[99,100]$. The transcription and biosynthesis of TNF is blocked by LMP-420-(2-amino-6-chloro-9-[5(dihydroxyboryl)-pentyl] purine-, 
a purine nucleoside analog, which inhibits the replication of HIV-1 [101]. A considerable argument in favor of the use of anti-TNF therapy in HIV-1 infected patients is the safety of its use, since no increase in the mortality rate has been observed [102]. Furthermore, reports showed that HIV-1 symptoms are improved in treated patients, even if anti-TNF therapy could favor the immunosuppressive status of the patients and thereby increase the risk of opportunistic infections [103]. Anti-TNF therapy (etanercept, infliximab, adalimumab) has been shown to be well-tolerated in HIV-infected patients, with no enhancement of the rate of opportunistic infections, unless they had uncontrolled HIV replication [104-108]. Anti-TNF therapy may be helpful for the treatment of autoimmune diseases, without enhancing the plasma viremia in patients whose HIV disease is under control by cART $[103,109,110]$.
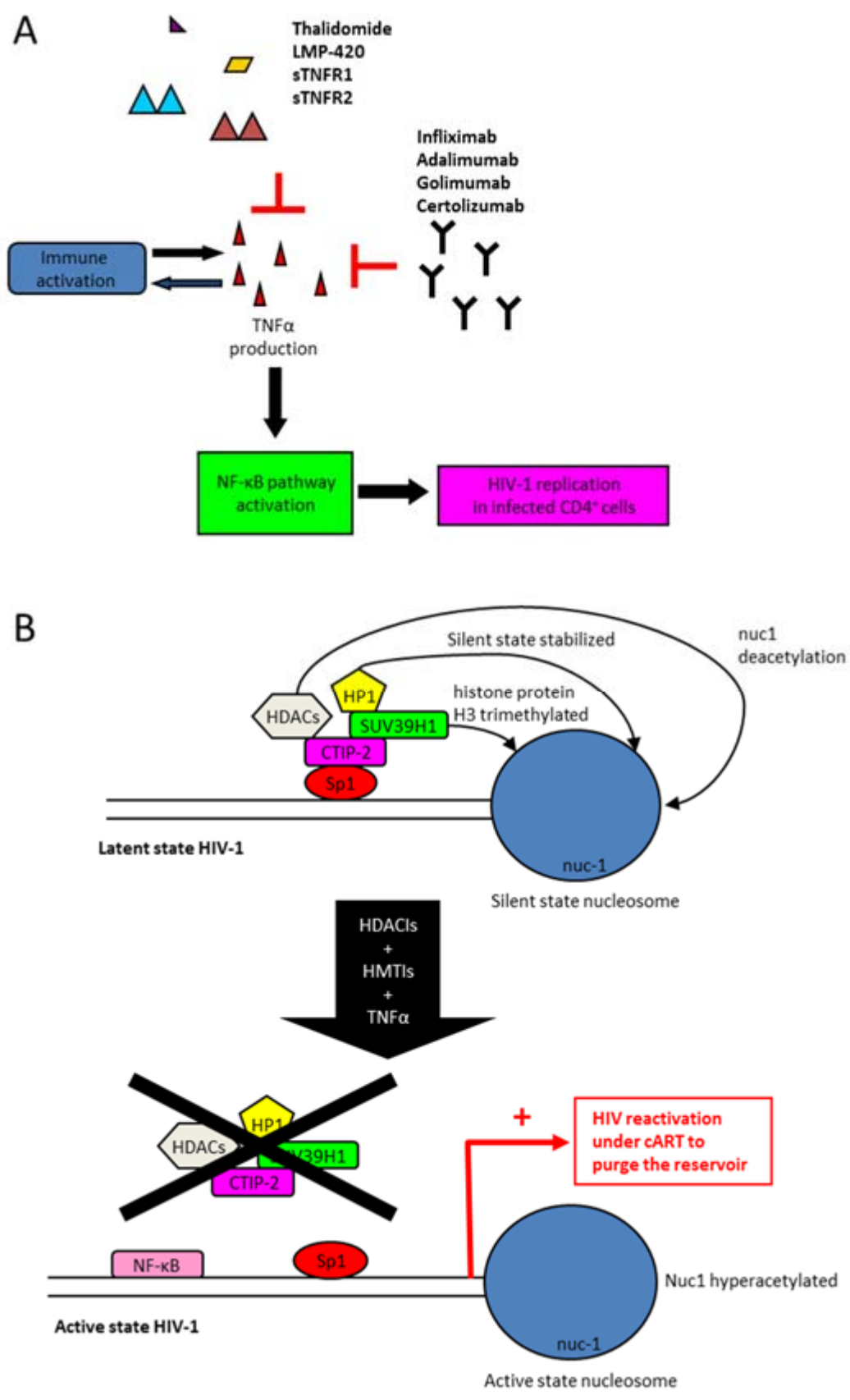

Figure 3. Cont. 
C

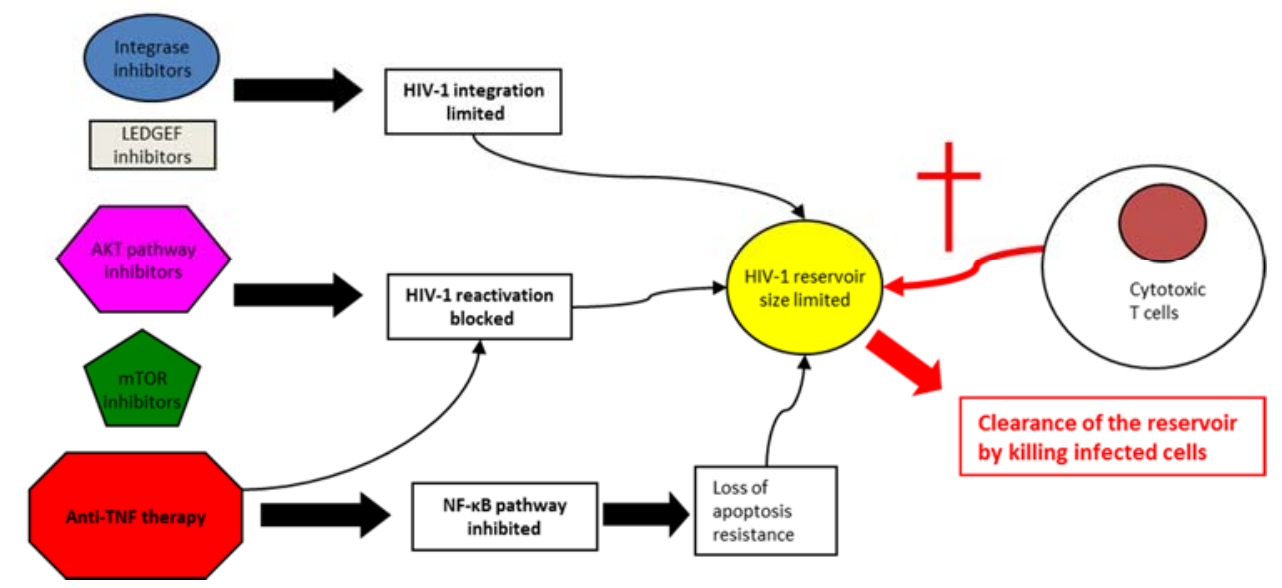

Figure 3. Potential TNF-based therapies to control HIV-1 infection. (A) Anti-TNF therapy against immune activation. Anti-TNF therapy limits immune activation triggered by HIV-1 infection. (B) TNF stimulation to enhance viral reactivation: the 'shock and kill' strategy. During HIV-1 latency, nuc-1 nucleosome is hypoacetylated. Coup-TFI interacting protein 2 (CTIP-2) interacts with Sp1, switching nuc-1 from transcriptionally active to a repressive state. Furthermore, CTIP-2 recruits histone deacetylase inhibitors (HDACs) that deacetylate the nuc-1 nucleosome. Suppressor of variegation 3-9 homolog 1 (SUV39H1) adds a trimethylation mark onto the histone protein H3. Furthermore, the heterochromatin protein 1 (HP1) protein stabilizes the nuc-1 in a transcriptionally silent state. The combination of TNF with HDAC inhibitors (HDACIs) or histone methyltransferase (HMT) inhibitors (HMTIs) can disrupt the HIV-1 latency. TNF and HDACIs can trigger the activation of transcriptional activators such as NF- $\mathrm{BB}$ (p50/p65 heterodimer). HDACIs prevent the formation of heterochromatin, resulting in nuc-1 hyperacetylation and remodeling, thereby alleviating the HIV transcriptional block. The use of TNF, HDACIs, and HMTIs enhances HIV-1 LTR transcription and could participate in the purge of the HIV-1 reservoir under combination antiretroviral therapy (cART). (C) Anti-TNF therapy to limit the size of the HIV-1 reservoir; the 'block and lock' strategy. Integrase inhibitors, lens epithelium-derived growth factor (LEDGF) inhibitors, mammalian target of rapamycin (mTOR) inhibitors and protein kinase B (AKT) inhibitors limit both HIV-1 integration and reactivation, thereby blocking and locking a limited amount of provirus, which then could be cleared by anti-HIV cytotoxic T-cells (CTLs). nuc-1: single nucleosome.

\section{Modulation of TNF Activity to Clear HIV-1 Reservoirs}

For a complete viral eradication in HIV-1 infected patients, the persistence of HIV-1 reservoirs is a major challenge [111-113]. Even in non-viremic patients that are under cART, the formation of an HIV-1 reservoir could result from the persistent immune activation observed especially in the presence of TNF [114]. TNF is a well-known activator of NF- $k B$, which is required to favor HIV-1 integration and the establishment of latency in CCL19-treated resting CD4+ T-cells [115]. Among HIV-1 reservoirs, resting or memory CD4+ T-cells are the main target [113]. Macrophages are another important HIV-1 reservoir, due to their resistance to apoptosis with sustained viral growth at low levels [116,117]. To eradicate the latent HIV-1 pool, an activation induced purging of HIV-1 in patients receiving cART has long been a proposed mechanism as a 'shock and kill' approach (Figure 3B) [118]. TNF has been used to reactivate HIV-1 from latently infected cells, although with limited levels of viral reactivation [119]. Although TNF consistently activates latent HIV-1 provirus in J-Lat cells, it is much less effective in primary CD4+ T-cells isolated from aviremic HIV-1 infected patients $[120,121]$. Moreover, toxicity associated with TNF treatment has been observed in some cases [122]. Therefore, to purge cellular reservoirs, several new drugs that target the epigenetic regulation of HIV-1 gene expression have been tested (Figure 3B). HIV-1 is synergistically 
reactivated from latency by a combination therapy, using both TNF and histone deacetylase inhibitors (HDACis) [123,124]. HIV-1 transcription is activated by the HDACis such as trichostatin A (TSA), trapoxin (TPX), valproic acid (VPA), and sodium butyrate (NaBut), which favor the remodeling of the single nucleosome (nuc-1) present in the HIV-1 promoter [125,126]. In view of the 'shock and kill' paradigm, forced HIV-1 gene expression elicited by HDACis and TNF in the presence of an effective cART regimen may lead to clearance of the pool of latently infected cells $[119,125,127]$. In addition to the direct effect of HDACis on HIV-1 transcription, the enhancement of TNF mediated NF- $\mathrm{KB}$ activation by HDACis could result in a sustained delay in I $\mathrm{B}$ alpha cytoplasmic reappearance [128]. To reactivate HIV-1 from latency in resting CD4+ T-cells of HIV-infected cART-treated patients, inhibitors of histone methyltransferase (HMTIs) have also been recently shown to be efficient [129]. Synergistic activation of HIV-1 expression by HDACi and prostratin, a NF- $\mathrm{kB}$ inducer that stimulates TNF production, favors viral reactivation $[119,130]$. Disulfiram also reactivates HIV-1 from latency in parallel to increasing the production of TNF in CD4+ T-cells [131,132]. The reactivation potential of prostratin is potentiated when used in combination with P-TEFb-releasing agents such as JQ1 [133]. Combining TNF treatment with other HIV-1 reactivating drugs such as HDACis, HMTIs, and prostratin enhances HIV-1 replication and ultimately could lead to the clearance of HIV reservoirs in infected patients under cART [134].

The 'shock and kill' paradigm has been challenged due to significant concerns about the feasibility and possible problems of this approach [135,136]. A novel paradigm, 'block and lock', has emerged recently and is based on the blockade of HIV reactivation from the latency reservoir to allow the clearance of actively infected cells by the immune system [137]. The 'block and lock' paradigm relies on the blockade of HIV reactivation, which could be based on several approaches (Figure 3C). First, treatments that block the signaling pathways involved in HIV-1 reactivation could be useful, including, among others, inhibitors of the mammalian target of rapamycin (mTOR) complex [138] and of the AKT pathway $[139,140]$, potentially as well as anti-TNF treatments. Anti-TNF therapy could be useful for limiting HIV-1 reactivation from latency through the inhibition of NF- $\mathrm{B}, \mathrm{MAPK}$, and p38 pathways. Second, treatments that limit new HIV-1 integration could also, in time, diminish the size of the reservoir. In addition to inhibitors of integrase and of lens epithelium-derived growth factor (LEDGF)/p75, which limit viral integration [141,142], anti-TNF therapy could curtail the size of the HIV-1 reservoir by controlling the cellular activation. Potential reactivation of the remaining reservoir could be subsequently cleared by HIV-specific cytotoxic T-cells (CTLs) (Figure 3C). During the initial differentiation of effector cells into memory CD4+ T-cells, NF- $\mathrm{B}$ activation enhances T-cell survival [143]. TNF/TNFR signaling may contribute, through its activation of NF- $k B$, to the establishment and maintenance of latent HIV-1 reservoirs in memory CD4+ T-cells [115]. Additionally, TNF stimulation of Nef-expressing HIV-infected T-cells inhibits CD4+ T-cell apoptosis and thereby could increase the size of the T-cell reservoir [144]. Thus, TNF-based therapy could be used to clear HIV-1 reservoirs in HIV-infected patients under cART and treated with latency reversing agents (LRA), which will reactivate a replication-competent provirus, resulting in the expression of viral proteins, such as Nef, at increased levels. In cART-treated patients, anti-TNF therapy could be an interesting approach to favor the clearance of latently infected cells by promoting their apoptosis after stimulation by LRA, in parallel to the action of HIV-specific CTLs.

\section{Conclusions}

Both immune activation and viral reservoirs are hallmarks of HIV-1 infection and involve the TNF/TNFR pathway. Thus, modulating TNF/TNFR pathway by new therapeutic approaches could limit immune activation and curtail the size of the HIV-1 reservoir in CART-treated patients with undetectable viremia, with the ultimate goal being to cure HIV-infected patients.

Acknowledgments: This work was supported by grants from the University of Franche-Comté, the Région Franche-Comté (RECH-FON12-000013), the Agence Nationale de Recherche sur le SIDA (ANRS, n 13543 and 13544), and HIVERA 2013 (EURECA project) to G.H. A.K. is a recipient of a postdoctoral fellowship of the Region Franche-Comté. 
Author Contributions: S.P., A.K., and G.H. wrote the paper.

Conflicts of Interest: The authors declare no conflict of interest. The founding sponsors had no role in the design of the study; in the collection, analyses, or interpretation of data; in the writing of the manuscript; or in the decision to publish the results.

\section{References}

1. Carswell, E.A.; Old, L.J.; Kassel, R.L.; Green, S.; Fiore, N.; Williamson, B. An endotoxin-induced serum factor that causes necrosis of tumors. Proc. Natl. Acad. Sci. USA 1975, 72, 3666-3670. [CrossRef] [PubMed]

2. Beutler, B.; Cerami, A. Cachectin and tumour necrosis factor as two sides of the same biological coin. Nature 1986, 320, 584-588. [CrossRef] [PubMed]

3. Bradley, J.R. TNF-mediated inflammatory disease. J. Pathol. 2008, 214, 149-160. [CrossRef] [PubMed]

4. Aggarwal, B.B.; Gupta, S.C.; Kim, J.H. Historical perspectives on tumor necrosis factor and its superfamily: 25 years later, a golden journey. Blood 2012, 119, 651-665. [CrossRef] [PubMed]

5. Moelants, E.A.V.; Mortier, A.; Van Damme, J.; Proost, P. Regulation of TNF- $\alpha$ with a focus on rheumatoid arthritis. Immunol. Cell Biol. 2013, 91, 393-401. [CrossRef] [PubMed]

6. Pennica, D.; Nedwin, G.E.; Hayflick, J.S.; Seeburg, P.H.; Derynck, R.; Palladino, M.A.; Kohr, W.J.; Aggarwal, B.B.; Goeddel, D.V. Human tumour necrosis factor: Precursor structure, expression and homology to lymphotoxin. Nature 1984, 312, 724-729. [CrossRef] [PubMed]

7. Kelker, H.C.; Oppenheim, J.D.; Stone-Wolff, D.; Henriksen-DeStefano, D.; Aggarwal, B.B.; Stevenson, H.C.; Vilcek, J. Characterization of human tumor necrosis factor produced by peripheral blood monocytes and its separation from lymphotoxin. Int. J. Cancer 1985, 36, 69-73. [CrossRef] [PubMed]

8. Herbein, G.; O'Brien, W.A. Tumor necrosis factor (TNF)- $\alpha$ and TNF receptors in viral pathogenesis. Proc. Soc. Exp. Biol. Med. 2000, 223, 241-257. [CrossRef] [PubMed]

9. Beutler, B.; van Huffel, C. Unraveling function in the TNF ligand and receptor families. Science 1994, 264, 667-668. [CrossRef] [PubMed]

10. Black, R.A.; Rauch, C.T.; Kozlosky, C.J.; Peschon, J.J.; Slack, J.L.; Wolfson, M.F.; Castner, B.J.; Stocking, K.L.; Reddy, P.; Srinivasan, S.; et al. A metalloproteinase disintegrin that releases tumour-necrosis factor- $\alpha$ from cells. Nature 1997, 385, 729-733. [CrossRef] [PubMed]

11. Grell, M.; Wajant, H.; Zimmermann, G.; Scheurich, P. The type 1 receptor (CD120a) is the high-affinity receptor for soluble tumor necrosis factor. Proc. Natl. Acad. Sci. USA 1998, 95, 570-575. [CrossRef] [PubMed]

12. Grell, M.; Douni, E.; Wajant, H.; Löhden, M.; Clauss, M.; Maxeiner, B.; Georgopoulos, S.; Lesslauer, W.; Kollias, G.; Pfizenmaier, K.; et al. The transmembrane form of tumor necrosis factor is the prime activating ligand of the $80 \mathrm{kDa}$ tumor necrosis factor receptor. Cell 1995, 83, 793-802. [CrossRef]

13. Hsu, H.; Xiong, J.; Goeddel, D.V. The TNF receptor 1-associated protein TRADD signals cell death and NF- $\mathrm{B}$ activation. Cell 1995, 81, 495-504. [CrossRef]

14. Hsu, H.; Shu, H.B.; Pan, M.G.; Goeddel, D.V. TRADD-TRAF2 and TRADD-FADD interactions define two distinct TNF receptor 1 signal transduction pathways. Cell 1996, 84, 299-308. [CrossRef]

15. DiDonato, J.A.; Hayakawa, M.; Rothwarf, D.M.; Zandi, E.; Karin, M. A cytokine-responsive IkB kinase that activates the transcription factor NF-kB. Nature 1997, 388, 548-554. [PubMed]

16. Mercurio, F.; Zhu, H.; Murray, B.W.; Shevchenko, A.; Bennett, B.L.; Li, J.; Young, D.B.; Barbosa, M.; Mann, M.;

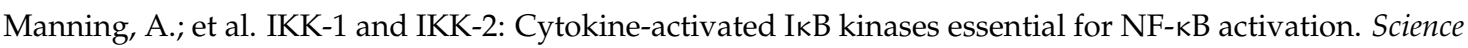
1997, 278, 860-866. [CrossRef] [PubMed]

17. Devin, A.; Cook, A.; Lin, Y.; Rodriguez, Y.; Kelliher, M.; Liu, Z. The distinct roles of TRAF2 and RIP in IKK activation by TNF-R1: TRAF2 recruits IKK to TNF-R1 while RIP mediates IKK activation. Immunity 2000, 12, 419-429. [CrossRef]

18. Natoli, G.; Costanzo, A.; Moretti, F.; Fulco, M.; Balsano, C.; Levrero, M. Tumor necrosis factor (TNF) receptor 1 signaling downstream of TNF receptor-associated factor 2. NUCLEAR FACTOR KB (NFKB)-INDUCING KINASE REQUIREMENT FOR ACTIVATION OF ACTIVATING PROTEIN 1 AND NFKB BUT NOT OF C-JUN N-TERMINAL KINASE/STRESS-ACTIVATED PROTEIN KINASE. J. Biol. Chem. 1997, 272, 26079-26082. [PubMed]

19. Grell, M.; Becke, F.M.; Wajant, H.; Männel, D.N.; Scheurich, P. TNF receptor type 2 mediates thymocyte proliferation independently of TNF receptor type 1. Eur. J. Immunol. 1998, 28, 257-263. [CrossRef] 
20. Gehr, G.; Gentz, R.; Brockhaus, M.; Loetscher, H.; Lesslauer, W. Both tumor necrosis factor receptor types mediate proliferative signals in human mononuclear cell activation. J. Immunol. 1992, 149, 911-917. [PubMed]

21. Zheng, L.; Fisher, G.; Miller, R.E.; Peschon, J.; Lynch, D.H.; Lenardo, M.J. Induction of apoptosis in mature T cells by tumour necrosis factor. Nature 1995, 377, 348-351. [CrossRef] [PubMed]

22. Herbein, G.; Montaner, L.J.; Gordon, S. Tumor necrosis factor alpha inhibits entry of human immunodeficiency virus type 1 into primary human macrophages: A selective role for the 75-kilodalton receptor. J. Virol. 1996, 70, 7388-7397. [PubMed]

23. Karsten, V.; Gordon, S.; Kirn, A.; Herbein, G. HIV-1 envelope glycoprotein gp120 down-regulates CD4 expression in primary human macrophages through induction of endogenous tumour necrosis factor- $\alpha$. Immunology 1996, 88, 55-60. [CrossRef] [PubMed]

24. Herbein, G.; Doyle, A.G.; Montaner, L.J.; Gordon, S. Lipopolysaccharide (LPS) down-regulates CD4 expression in primary human macrophages through induction of endogenous tumour necrosis factor (TNF) and IL-1 ß. Clin. Exp. Immunol. 1995, 102, 430-437. [CrossRef] [PubMed]

25. Di Marzio, P.; Tse, J.; Landau, N.R. Chemokine receptor regulation and HIV type 1 tropism in monocyte-macrophages. AIDS Res. Hum. Retrovir. 1998, 14, 129-138. [CrossRef] [PubMed]

26. Herbein, G.; Gordon, S. 55- and 75-kilodalton tumor necrosis factor receptors mediate distinct actions in regard to human immunodeficiency virus type 1 replication in primary human macrophages. J. Virol. 1997, 71, 4150-4156. [PubMed]

27. Coffey, M.J.; Woffendin, C.; Phare, S.M.; Strieter, R.M.; Markovitz, D.M. RANTES inhibits HIV-1 replication in human peripheral blood monocytes and alveolar macrophages. Am. J. Physiol. 1997, 272, L1025-L1029. [PubMed]

28. Simmons, G.; Clapham, P.R.; Picard, L.; Offord, R.E.; Rosenkilde, M.M.; Schwartz, T.W.; Buser, R.; Wells, T.N.; Proudfoot, A.E. Potent inhibition of HIV-1 infectivity in macrophages and lymphocytes by a novel CCR5 antagonist. Science 1997, 276, 276-279. [CrossRef] [PubMed]

29. Lane, B.R.; Markovitz, D.M.; Woodford, N.L.; Rochford, R.; Strieter, R.M.; Coffey, M.J. TNF- $\alpha$ inhibits HIV-1 replication in peripheral blood monocytes and alveolar macrophages by inducing the production of RANTES and decreasing C-C chemokine receptor 5 (CCR5) expression. J. Immunol. 1999, 163, 3653-3661. [PubMed]

30. McManus, C.M.; Brosnan, C.F.; Berman, J.W. Cytokine induction of MIP-1 $\alpha$ and MIP-1 $\beta$ in human fetal microglia. J. Immunol. 1998, 160, 1449-1455. [PubMed]

31. Kitai, R.; Zhao, M.L.; Zhang, N.; Hua, L.L.; Lee, S.C. Role of MIP-1beta and RANTES in HIV-1 infection of microglia: Inhibition of infection and induction by IFN $\beta$. J. Neuroimmunol. 2000, 110, 230-239. [CrossRef]

32. Gaur, U.; Aggarwal, B.B. Regulation of proliferation, survival and apoptosis by members of the TNF superfamily. Biochem. Pharmacol. 2003, 66, 1403-1408. [CrossRef]

33. Ono, K.; Han, J. The p38 signal transduction pathway: Activation and function. Cell. Signal. 2000, 12, 1-13. [CrossRef]

34. Lee, J.C.; Laydon, J.T.; McDonnell, P.C.; Gallagher, T.F.; Kumar, S.; Green, D.; McNulty, D.; Blumenthal, M.J.; Heys, J.R.; Landvatter, S.W. A protein kinase involved in the regulation of inflammatory cytokine biosynthesis. Nature 1994, 372, 739-746. [CrossRef] [PubMed]

35. Baud, V.; Karin, M. Signal transduction by tumor necrosis factor and its relatives. Trends Cell Biol. 2001, 11, 372-377. [CrossRef]

36. Grivennikov, S.I.; Kuprash, D.V.; Liu, Z.-G.; Nedospasov, S.A. Intracellular signals and events activated by cytokines of the tumor necrosis factor superfamily: From simple paradigms to complex mechanisms. Int. Rev. Cytol. 2006, 252, 129-161. [PubMed]

37. Nakano, H. Signaling crosstalk between NF-kB and JNK. Trends Immunol. 2004, 25, 402-405. [CrossRef] [PubMed]

38. Duh, E.J.; Maury, W.J.; Folks, T.M.; Fauci, A.S.; Rabson, A.B. Tumor necrosis factor alpha activates human immunodeficiency virus type 1 through induction of nuclear factor binding to the NF- $\mathrm{KB}$ sites in the long terminal repeat. Proc. Natl. Acad. Sci. USA 1989, 86, 5974-5978. [CrossRef] [PubMed]

39. Griffin, G.E.; Leung, K.; Folks, T.M.; Kunkel, S.; Nabel, G.J. Activation of HIV gene expression during monocyte differentiation by induction of NF-kappa B. Nature 1989, 339, 70-73. [CrossRef] [PubMed]

40. Okamoto, T.; Matsuyama, T.; Mori, S.; Hamamoto, Y.; Kobayashi, N.; Yamamoto, N.; Josephs, S.F.; Wong-Staal, F.; Shimotohno, K. Augmentation of human immunodeficiency virus type 1 gene expression by tumor necrosis factor $\alpha$. AIDS Res. Hum. Retrovir. 1989, 5, 131-138. [CrossRef] [PubMed] 
41. Osborn, L.; Kunkel, S.; Nabel, G.J. Tumor necrosis factor alpha and interleukin 1 stimulate the human immunodeficiency virus enhancer by activation of the nuclear factor kappa B. Proc. Natl. Acad. Sci. USA 1989, 86, 2336-2340. [CrossRef] [PubMed]

42. Takahashi, Y.; Tanaka, Y.; Yamashita, A.; Koyanagi, Y.; Nakamura, M.; Yamamoto, N. OX40 stimulation by gp34/OX40 ligand enhances productive human immunodeficiency virus type 1 infection. J. Virol. 2001, 75, 6748-6757. [CrossRef] [PubMed]

43. Clerici, M.; Galli, M.; Bosis, S.; Gervasoni, C.; Moroni, M.; Norbiato, G. Immunoendocrinologic abnormalities in human immunodeficiency virus infection. Ann. N. Y. Acad. Sci. 2000, 917, 956-961. [CrossRef] [PubMed]

44. Herbein, G.; Khan, K.A. Is HIV infection a TNF receptor signalling-driven disease? Trends Immunol. 2008, 29, 61-67. [CrossRef] [PubMed]

45. Arokium, H.; Kamata, M.; Chen, I. Virion-associated Vpr of human immunodeficiency virus type 1 triggers activation of apoptotic events and enhances fas-induced apoptosis in human T cells. J. Virol. 2009, 83, 11283-11297. [CrossRef] [PubMed]

46. Andersen, J.L.; DeHart, J.L.; Zimmerman, E.S.; Ardon, O.; Kim, B.; Jacquot, G.; Benichou, S.; Planelles, V. HIV-1 Vpr-induced apoptosis is cell cycle dependent and requires Bax but not ANT. PLoS Pathog. 2006, 2, e127. [CrossRef] [PubMed]

47. Kogan, M.; Deshmane, S.; Sawaya, B.E.; Gracely, E.J.; Khalili, K.; Rappaport, J. Inhibition of NF-кB activity by HIV-1 Vpr is dependent on Vpr binding protein. J. Cell. Physiol. 2013, 228, 781-790. [CrossRef] [PubMed]

48. Conti, L.; Rainaldi, G.; Matarrese, P.; Varano, B.; Rivabene, R.; Columba, S.; Sato, A.; Belardelli, F.; Malorni, W.; Gessani, S. The HIV-1 VPR protein acts as a negative regulator of apoptosis in a human lymphoblastoid T cell line: Possible implications for the pathogenesis of AIDS. J. Exp. Med. 1998, 187, 403-413. [CrossRef] [PubMed]

49. Malim, M.H.; Emerman, M. HIV-1 accessory proteins-Ensuring viral survival in a hostile environment. Cell Host Microbe 2008, 3, 388-398. [CrossRef] [PubMed]

50. Hoshino, S.; Konishi, M.; Mori, M.; Shimura, M.; Nishitani, C.; Kuroki, Y.; Koyanagi, Y.; Kano, S.; Itabe, H.; Ishizaka, Y. HIV-1 Vpr induces TLR4/MyD88-mediated IL-6 production and reactivates viral production from latency. J. Leukoc. Biol. 2010, 87, 1133-1143. [CrossRef] [PubMed]

51. Varin, A.; Decrion, A.-Z.; Sabbah, E.; Quivy, V.; Sire, J.; Van Lint, C.; Roques, B.P.; Aggarwal, B.B.; Herbein, G. Synthetic Vpr protein activates activator protein-1, c-Jun N-terminal kinase, and NF- $\mathrm{B}$ and stimulates HIV-1 transcription in promonocytic cells and primary macrophages. J. Biol. Chem. 2005, 280, 42557-42567. [CrossRef] [PubMed]

52. Roux, P.; Alfieri, C.; Hrimech, M.; Cohen, E.A.; Tanner, J.E. Activation of transcription factors NF- $\mathrm{kB}$ and NF-IL-6 by human immunodeficiency virus type 1 protein R (VPR) induces interleukin-8 expression. J. Virol. 2000, 74, 4658-4665. [CrossRef] [PubMed]

53. Roesch, F.; Richard, L.; Rua, R.; Porrot, F.; Casartelli, N.; Schwartz, O. VPR Enhances Tumor Necrosis Factor Production by HIV-1-Infected T Cells. J. Virol. 2015, 89, 12118-12130. [CrossRef] [PubMed]

54. Sawaya, B.E.; Khalili, K.; Gordon, J.; Taube, R.; Amini, S. Cooperative interaction between HIV-1 regulatory proteins Tat and VPR modulates transcription of the viral genome. J. Biol. Chem. 2000, 275, 35209-35214. [CrossRef] [PubMed]

55. Muthumani, K.; Choo, A.Y.; Zong, W.-X.; Madesh, M.; Hwang, D.S.; Premkumar, A.; Thieu, K.P.; Emmanuel, J.; Kumar, S.; Thompson, C.B.; et al. The HIV-1 Vpr and glucocorticoid receptor complex is a gain-of-function interaction that prevents the nuclear localization of PARP-1. Nat. Cell Biol. 2006, 8, 170-179. [CrossRef] [PubMed]

56. Herbein, G. TNF and HIV-1 Nef: An Intimate Interplay. EBioMedicine 2016, 13, 25-26. [CrossRef] [PubMed]

57. Lenassi, M.; Cagney, G.; Liao, M.; Vaupotic, T.; Bartholomeeusen, K.; Cheng, Y.; Krogan, N.J.; Plemenitas, A.; Peterlin, B.M. HIV NEF is secreted in exosomes and triggers apoptosis in bystander CD4+ T cells. Traffic 2010, 11, 110-122. [CrossRef] [PubMed]

58. Varin, A.; Manna, S.K.; Quivy, V.; Decrion, A.-Z.; Van Lint, C.; Herbein, G.; Aggarwal, B.B. Exogenous Nef protein activates NF- $\mathrm{KB}, \mathrm{AP}-1$, and c-Jun N-terminal kinase and stimulates HIV transcription in promonocytic cells. Role in AIDS pathogenesis. J. Biol. Chem. 2003, 278, 2219-2227. [CrossRef] [PubMed] 
59. Olivetta, E.; Percario, Z.; Fiorucci, G.; Mattia, G.; Schiavoni, I.; Dennis, C.; Jäger, J.; Harris, M.; Romeo, G.; Affabris, E.; et al. HIV-1 Nef induces the release of inflammatory factors from human monocyte/macrophages: Involvement of Nef endocytotic signals and NF-kB activation. J. Immunol. 2003, 170, 1716-1727. [CrossRef] [PubMed]

60. Mangino, G.; Percario, Z.A.; Fiorucci, G.; Vaccari, G.; Manrique, S.; Romeo, G.; Federico, M.; Geyer, M.; Affabris, E. In vitro treatment of human monocytes/macrophages with myristoylated recombinant Nef of human immunodeficiency virus type 1 leads to the activation of mitogen-activated protein kinases, IкB kinases, and interferon regulatory factor 3 and to the release of beta interferon. J. Virol. 2007, 81, 2777-2791. [PubMed]

61. Olivetta, E.; Tirelli, V.; Chiozzini, C.; Scazzocchio, B.; Romano, I.; Arenaccio, C.; Sanchez, M. HIV-1 Nef impairs key functional activities in human macrophages through CD36 downregulation. PLoS ONE 2014, 9, e93699. [CrossRef] [PubMed]

62. Herbein, G.; Varin, A.; Larbi, A.; Fortin, C.; Mahlknecht, U.; Fulop, T.; Aggarwal, B. NEF and TNF $\alpha$ are Coplayers that Favor HIV-1 Replication in Monocytic Cells and Primary Macrophages. Curr. HIV Res. 2008, 6, 117-129. [CrossRef] [PubMed]

63. Khan, K.A.; Abbas, W.; Varin, A.; Kumar, A.; Di Martino, V.; Dichamp, I.; Herbein, G. HIV-1 Nef interacts with HCV Core, recruits TRAF2, TRAF5 and TRAF6, and stimulates HIV-1 replication in macrophages. J. Innate Immun. 2013, 5, 639-656. [CrossRef] [PubMed]

64. Ostalecki, C.; Wittki, S.; Lee, J.-H.; Geist, M.M.; Tibroni, N.; Harrer, T.; Schuler, G.; Fackler, O.T.; Baur, A.S. HIV NEF- and Notch1-dependent Endocytosis of ADAM17 Induces Vesicular TNF Secretion in Chronic HIV Infection. EBioMedicine 2016, 13, 294-304. [CrossRef] [PubMed]

65. Schorey, J.S.; Harding, C.V. Extracellular vesicles and infectious diseases: New complexity to an old story. J. Clin. Investig. 2016, 126, 1181-1189. [CrossRef] [PubMed]

66. Arenaccio, C.; Chiozzini, C.; Columba-Cabezas, S.; Manfredi, F.; Federico, M. Cell activation and HIV-1 replication in unstimulated CD4+ T lymphocytes ingesting exosomes from cells expressing defective HIV-1. Retrovirology 2014, 11, 46. [CrossRef] [PubMed]

67. Arenaccio, C.; Chiozzini, C.; Columba-Cabezas, S.; Manfredi, F.; Affabris, E.; Baur, A.; Federico, M. Exosomes from human immunodeficiency virus type 1 (HIV-1)-infected cells license quiescent CD4+ T lymphocytes to replicate HIV-1 through a Nef- and ADAM17-dependent mechanism. J. Virol. 2014, 88, 11529-11539. [CrossRef] [PubMed]

68. Sampey, G.C.; Saifuddin, M.; Schwab, A.; Barclay, R.; Punya, S.; Chung, M.-C.; Hakami, R.M.; Zadeh, M.A.; Lepene, B.; Klase, Z.A.; et al. Exosomes from HIV-1-infected cells stimulate production of pro-inflammatory cytokines through trans-activating response (TAR) RNA. J. Biol. Chem. 2016, 291, 1251-1266. [CrossRef] [PubMed]

69. Kumar, A.; Manna, S.K.; Dhawan, S.; Aggarwal, B.B. HIV-Tat protein activates c-Jun N-terminal kinase and activator protein-1. J. Immunol. 1998, 161, 776-781. [PubMed]

70. Planès, R.; Ben Haij, N.; Leghmari, K.; Serrero, M.; BenMohamed, L.; Bahraoui, E. HIV-1 Tat protein activates both the MyD88 and TRIF pathways to induce tumor necrosis factor $\alpha$ and interleukin-10 in human monocytes. J. Virol. 2016, 90, 5886-5898. [CrossRef] [PubMed]

71. Abbas, W.; Herbein, G. T-Cell Signaling in HIV-1 Infection. Open Virol. J. 2013, 7, 57-71. [CrossRef] [PubMed]

72. Rieckmann, P.; Poli, G.; Fox, C.H.; Kehrl, J.H.; Fauci, A.S. Recombinant gp120 specifically enhances tumor necrosis factor- $\alpha$ production and Ig secretion in B lymphocytes from HIV-infected individuals but not from seronegative donors. J. Immunol. 1991, 147, 2922-2927. [PubMed]

73. Merrill, J.E.; Koyanagi, Y.; Chen, I.S. Interleukin-1 and tumor necrosis factor $\alpha$ can be induced from mononuclear phagocytes by human immunodeficiency virus type 1 binding to the CD4 receptor. J. Virol. 1989, 63, 4404-4408. [PubMed]

74. Khanna, K.V.; Yu, X.F.; Ford, D.H.; Ratner, L.; Hildreth, J.K.; Markham, R.B. Differences among HIV-1 variants in their ability to elicit secretion of TNF- $\alpha$. J. Immunol. 2000, 164, 1408-1415. [CrossRef] [PubMed]

75. Lee, C.; Tomkowicz, B.; Freedman, B.D.; Collman, R.G. HIV-1 gp120-induced TNF- $\{\alpha\}$ production by primary human macrophages is mediated by phosphatidylinositol-3 (PI-3) kinase and mitogen-activated protein (MAP) kinase pathways. J. Leukoc. Biol. 2005, 78, 1016-1023. [CrossRef] [PubMed] 
76. Zheng, W.; Ouyang, H.; Zheng, X.; Liu, S.; Mata, M.; Fink, D.J.; Hao, S. Glial TNF $\alpha$ in the spinal cord regulates neuropathic pain induced by HIV gp120 application in rats. Mol. Pain 2011, 7, 40. [CrossRef] [PubMed]

77. Furler, R.L.; Uittenbogaart, C.H. Signaling through the P38 and ERK pathways: A common link between HIV replication and the immune response. Immunol. Res. 2010, 48, 99-109. [CrossRef] [PubMed]

78. Rychert, J.; Strick, D.; Bazner, S.; Robinson, J.; Rosenberg, E. Detection of HIV gp120 in plasma during early HIV infection is associated with increased proinflammatory and immunoregulatory cytokines. AIDS Res. Hum. Retrovir. 2010, 26, 1139-1145. [CrossRef] [PubMed]

79. Herbein, G.; Mahlknecht, U.; Batliwalla, F.; Gregersen, P.; Pappas, T.; Butler, J.; O’Brien, W.A.; Verdin, E. Apoptosis of CD8+ T cells is mediated by macrophages through interaction of HIV gp120 with chemokine receptor CXCR4. Nature 1998, 395, 189-194. [PubMed]

80. Alfano, M.; Alfano, M.; Banki, Z.; Borde, C.; Bristow, C.L.; Caruz, A.; Chang, T.L.; Cortes, J.; Eugen-Olsen, J.; Fibla, J.; et al. Soluble Factors Mediating Innate Immune Responses to HIV Infection; Bentham Science Publishers: Chennai, India, 2010.

81. Zangerle, R.; Gallati, H.; Sarcletti, M.; Wachter, H.; Fuchs, D. Tumor necrosis factor $\alpha$ and soluble tumor necrosis factor receptors in individuals with human immunodeficiency virus infection. Immunol. Lett. 1994, 41, 229-234. [CrossRef]

82. Croft, M.; Benedict, C.A.; Ware, C.F. Clinical targeting of the TNF and TNFR superfamilies. Nat. Rev. Drug Discov. 2013, 12, 147-168. [CrossRef] [PubMed]

83. Wendling, D.; Herbein, G. TNF $\alpha$ antagonist therapy in patients with joint disease and chronic viral infection. Jt. Bone Spine 2007, 74, 407-409. [CrossRef] [PubMed]

84. Knight, D.M.; Trinh, H.; Le, J.; Siegel, S.; Shealy, D.; McDonough, M.; Scallon, B.; Moore, M.A.; Vilcek, J.; Daddona, P. Construction and initial characterization of a mouse-human chimeric anti-TNF antibody. Mol. Immunol. 1993, 30, 1443-1453. [CrossRef]

85. Goel, N.; Stephens, S. Certolizumab pegol. MAbs 2010, 2, 137-147. [CrossRef] [PubMed]

86. Aukrust, P.; Liabakk, N.B.; Müller, F.; Lien, E.; Espevik, T.; Frøland, S.S. Serum levels of tumor necrosis factor-alpha (TNF $\alpha$ ) and soluble TNF receptors in human immunodeficiency virus type 1 infection-correlations to clinical, immunologic, and virologic parameters. J. Infect. Dis. 1994, 169, 420-424. [CrossRef] [PubMed]

87. Whalen, C.; Horsburgh, C.R.; Hom, D.; Lahart, C.; Simberkoff, M.; Ellner, J. Accelerated course of human immunodeficiency virus infection after tuberculosis. Am. J. Respir. Crit. Care Med. 1995, 151, 129-135. [CrossRef] [PubMed]

88. Sereti, I.; Krebs, S.J.; Phanuphak, N.; Fletcher, J.L.; Slike, B.; Pinyakorn, S.; O'Connell, R.J.; Rupert, A.; Chomont, N.; Valcour, V.; et al. Persistent, Albeit Reduced, Chronic Inflammation in Persons Starting Antiretroviral Therapy in Acute HIV Infection. Clin. Infect. Dis. 2017, 64, 124-131. [CrossRef] [PubMed]

89. Wilson, E.M.P.; Singh, A.; Hullsiek, K.H.; Gibson, D.; Henry, W.K.; Lichtenstein, K.; Önen, N.F.; Kojic, E.; Patel, P.; Brooks, J.T.; et al. Study to understand the natural history of HIV/AIDS in the era of effective therapy (SUN study) investigators monocyte-activation phenotypes are associated with biomarkers of inflammation and coagulation in chronic HIV infection. J. Infect. Dis. 2014, 210, 1396-1406. [CrossRef] [PubMed]

90. Castillo-Mancilla, J.R.; Brown, T.T.; Erlandson, K.M.; Palella, F.J.; Gardner, E.M.; Macatangay, B.J.C.; Breen, E.C.; Jacobson, L.P.; Anderson, P.L.; Wada, N.I. Suboptimal adherence to combination antiretroviral therapy is associated with higher levels of inflammation despite HIV suppression. Clin. Infect. Dis. 2016, 63, 1661-1667. [CrossRef] [PubMed]

91. Wada, N.I.; Jacobson, L.P.; Margolick, J.B.; Breen, E.C.; Macatangay, B.; Penugonda, S.; Martínez-Maza, O.; Bream, J.H. The effect of HAART-induced HIV suppression on circulating markers of inflammation and immune activation. AIDS 2015, 29, 463-471. [CrossRef] [PubMed]

92. Dezube, B.J.; Lederman, M.M.; Chapman, B.; Georges, D.L.; Dogon, A.L.; Mudido, P.; Reis-Lishing, J.; Cheng, S.L.; Silberman, S.L.; Crumpacker, C.S. The effect of tenidap on cytokines, acute-phase proteins, and virus load in human immunodeficiency virus (HIV)-infected patients: Correlation between plasma HIV-1 RNA and proinflammatory cytokine levels. J. Infect. Dis. 1997, 176, 807-810. [CrossRef] [PubMed]

93. Valdez, H.; Lederman, M.M. Cytokines and cytokine therapies in HIV infection. AIDS Clin. Rev. 1997, 187-228. 
94. Beyer, M.; Abdullah, Z.; Chemnitz, J.M.; Maisel, D.; Sander, J.; Lehmann, C.; Thabet, Y.; Shinde, P.V.; Schmidleithner, L.; Köhne, M.; et al. Tumor-necrosis factor impairs CD4(+) T cell-mediated immunological control in chronic viral infection. Nat. Immunol. 2016, 17, 593-603. [CrossRef] [PubMed]

95. Aderka, D. The potential biological and clinical significance of the soluble tumor necrosis factor receptors. Cytokine Growth Factor Rev. 1996, 7, 231-240. [CrossRef]

96. Brockhaus, M. Soluble TNF receptor: What is the significance? Intensive Care Med. 1997, 23, 808-809. [CrossRef] [PubMed]

97. Xanthoulea, S.; Pasparakis, M.; Kousteni, S.; Brakebusch, C.; Wallach, D.; Bauer, J.; Lassmann, H.; Kollias, G. Tumor necrosis factor (TNF) receptor shedding controls thresholds of innate immune activation that balance opposing TNF functions in infectious and inflammatory diseases. J. Exp. Med. 2004, 200, 367-376. [CrossRef] [PubMed]

98. Decrion, A.Z.; Dichamp, I.; Varin, A.; Herbein, G. HIV and inflammation. Curr. HIV Res. 2005, 3, $243-259$. [CrossRef] [PubMed]

99. Marriott, J.B.; Cookson, S.; Carlin, E.; Youle, M.; Hawkins, D.A.; Nelson, M.; Pearson, M.; Vaughan, A.N.; Gazzard, B.; Dalgleish, A.G. A double-blind placebo-controlled phase II trial of thalidomide in asymptomatic HIV-positive patients: Clinical tolerance and effect on activation markers and cytokines. AIDS Res. Hum. Retrovir. 1997, 13, 1625-1631. [CrossRef] [PubMed]

100. Wallis, R.S.; Nsubuga, P.; Whalen, C.; Mugerwa, R.D.; Okwera, A.; Oette, D.; Jackson, J.B.; Johnson, J.L.; Ellner, J.J. Pentoxifylline therapy in human immunodeficiency virus-seropositive persons with tuberculosis: A randomized, controlled trial. J. Infect. Dis. 1996, 174, 727-733. [CrossRef] [PubMed]

101. Haraguchi, S.; Day, N.K.; Kamchaisatian, W.; Beigier-Pompadre, M.; Stenger, S.; Tangsinmankong, N.; Sleasman, J.W.; Pizzo, S.V.; Cianciolo, G.J. LMP-420, a small-molecule inhibitor of TNF- $\alpha$, reduces replication of HIV-1 and Mycobacterium tuberculosis in human cells. AIDS Res. Ther. 2006, 3, 8. [CrossRef] [PubMed]

102. Ting, P.T.; Koo, J.Y. Use of etanercept in human immunodeficiency virus (HIV) and acquired immunodeficiency syndrome (AIDS) patients. Int. J. Dermatol. 2006, 45, 689-692. [CrossRef] [PubMed]

103. Calabrese, L.H.; Zein, N.; Vassilopoulos, D. Safety of antitumour necrosis factor (anti-TNF) therapy in patients with chronic viral infections: Hepatitis C, hepatitis B, and HIV infection. Ann. Rheum. Dis. 2004, 63 (Suppl. 2), ii18-ii24. [CrossRef] [PubMed]

104. Sha, B.E.; Valdez, H.; Gelman, R.S.; Landay, A.L.; Agosti, J.; Mitsuyasu, R.; Pollard, R.B.; Mildvan, D.; Namkung, A.; Ogata-Arakaki, D.M.; et al. Effect of etanercept (Enbrel) on interleukin 6, tumor necrosis factor $\alpha$, and markers of immune activation in HIV-infected subjects receiving interleukin 2. AIDS Res. Hum. Retrovir. 2002, 18, 661-665. [CrossRef] [PubMed]

105. Wallis, R.S.; Kyambadde, P.; Johnson, J.L.; Horter, L.; Kittle, R.; Pohle, M.; Ducar, C.; Millard, M.; Mayanja-Kizza, H.; Whalen, C.; et al. A study of the safety, immunology, virology, and microbiology of adjunctive etanercept in HIV-1-associated tuberculosis. AIDS 2004, 18, 257-264. [CrossRef] [PubMed]

106. Walker, R.E.; Spooner, K.M.; Kelly, G.; McCloskey, R.V.; Woody, J.N.; Falloon, J.; Baseler, M.; Piscitelli, S.C.; Davey, R.T.; Polis, M.A.; et al. Inhibition of immunoreactive tumor necrosis factor- $\alpha$ by a chimeric antibody in patients infected with human immunodeficiency virus type 1. J. Infect. Dis. 1996, 174, 63-68. [CrossRef] [PubMed]

107. Gaylis, N. Infliximab in the treatment of an HIV positive patient with Reiter's syndrome. J. Rheumatol. 2003, 30, 407-411. [PubMed]

108. Gallitano, S.M.; McDermott, L.; Brar, K.; Lowenstein, E. Use of tumor necrosis factor (TNF) inhibitors in patients with HIV/AIDS. J. Am. Acad. Dermatol. 2016, 74, 974-980. [CrossRef] [PubMed]

109. Cepeda, E.J.; Williams, F.M.; Ishimori, M.L.; Weisman, M.H.; Reveille, J.D. The use of anti-tumour necrosis factor therapy in HIV-positive individuals with rheumatic disease. Ann. Rheum. Dis. 2008, 67, 710-712. [CrossRef] [PubMed]

110. Wangsiricharoen, S.; Ligon, C.; Gedmintas, L.; Dehrab, A.; Tungsiripat, M.; Bingham, C.; Lozada, C.; Calabrese, L. The rates of serious infections in HIV-infected patients who received tumor necrosis factor (TNF)- $\alpha$ inhibitor therapy for concomitant autoimmune diseases. Arthritis Care Res. 2016, 69, 449-452. [CrossRef] [PubMed]

111. Chun, T.W.; Fauci, A.S. Latent reservoirs of HIV: Obstacles to the eradication of virus. Proc. Natl. Acad. Sci. USA 1999, 96, 10958-10961. [CrossRef] [PubMed] 
112. Chomont, N.; El-Far, M.; Ancuta, P.; Trautmann, L.; Procopio, F.A.; Yassine-Diab, B.; Boucher, G.; Boulassel, M.-R.; Ghattas, G.; Brenchley, J.M.; et al. HIV reservoir size and persistence are driven by T cell survival and homeostatic proliferation. Nat. Med. 2009, 15, 893-900. [CrossRef] [PubMed]

113. Abbas, W.; Herbein, G. Molecular understanding of HIV-1 latency. Adv. Virol. 2012, 2012, 574967. [CrossRef] [PubMed]

114. Siliciano, J.D.; Siliciano, R.F. Recent developments in the effort to cure HIV infection: Going beyond $\mathrm{N}=1$. J. Clin. Investig. 2016, 126, 409-414. [CrossRef] [PubMed]

115. Saleh, S.; Lu, H.K.; Evans, V.; Harisson, D.; Zhou, J.; Jaworowski, A.; Sallmann, G.; Cheong, K.Y.; Mota, T.M.; Tennakoon, S.; et al. HIV integration and the establishment of latency in CCL19-treated resting CD4(+) T cells require activation of NF- $\mathrm{kB}$. Retrovirology 2016, 13, 49. [CrossRef] [PubMed]

116. Abbas, W.; Khan, K.A.; Kumar, A.; Tripathy, M.K.; Dichamp, I.; Keita, M.; Mahlknecht, U.; Rohr, O.; Herbein, G. Blockade of BFA-mediated apoptosis in macrophages by the HIV-1 Nef protein. Cell Death Dis. 2014, 5, e1080. [CrossRef] [PubMed]

117. Abbas, W.; Tariq, M.; Iqbal, M.; Kumar, A.; Herbein, G. Eradication of HIV-1 from the macrophage reservoir: An uncertain goal? Viruses 2015, 7, 1578-1598. [CrossRef] [PubMed]

118. Chun, T.W.; Engel, D.; Mizell, S.B.; Ehler, L.A.; Fauci, A.S. Induction of HIV-1 replication in latently infected CD4+ T cells using a combination of cytokines. J. Exp. Med. 1998, 188, 83-91. [CrossRef] [PubMed]

119. Reuse, S.; Calao, M.; Kabeya, K.; Guiguen, A.; Gatot, J.-S.; Quivy, V.; Vanhulle, C.; Lamine, A.; Vaira, D.; Demonte, D.; et al. Synergistic activation of HIV-1 expression by deacetylase inhibitors and prostratin: Implications for treatment of latent infection. PLoS ONE 2009, 4, e6093. [CrossRef] [PubMed]

120. Chan, J.K.L.; Greene, W.C. NF-кB/Rel: Agonist and antagonist roles in HIV-1 latency. Curr. Opin. HIV AIDS 2011, 6, 12-18. [CrossRef] [PubMed]

121. Burnett, J.C.; Lim, K.-I.; Calafi, A.; Rossi, J.J.; Schaffer, D.V.; Arkin, A.P. Combinatorial latency reactivation for HIV-1 subtypes and variants. J. Virol. 2010, 84, 5958-5974. [CrossRef] [PubMed]

122. Cummins, N.W.; Badley, A.D. Mechanisms of HIV-associated lymphocyte apoptosis: 2010. Cell Death Dis. 2010, 1, e99. [CrossRef] [PubMed]

123. Quivy, V.; Adam, E.; Collette, Y.; Demonte, D.; Chariot, A.; Vanhulle, C.; Berkhout, B.; Castellano, R.; de Launoit, Y.; Burny, A.; et al. Synergistic activation of human immunodeficiency virus type 1 promoter activity by NF-kB and inhibitors of deacetylases: Potential perspectives for the development of therapeutic strategies. J. Virol. 2002, 76, 11091-11103. [CrossRef] [PubMed]

124. Vandergeeten, C.; Quivy, V.; Moutschen, M.; Van Lint, C.; Piette, J.; Legrand-Poels, S. HIV-1 protease inhibitors do not interfere with provirus transcription and host cell apoptosis induced by combined treatment TNF- $\alpha+$ TSA. Biochem. Pharmacol. 2007, 73, 1738-1748. [CrossRef] [PubMed]

125. Demonté, D.; Quivy, V.; Colette, Y.; Van Lint, C. Administration of HDAC inhibitors to reactivate HIV-1 expression in latent cellular reservoirs: Implications for the development of therapeutic strategies. Biochem. Pharmacol. 2004, 68, 1231-1238. [CrossRef] [PubMed]

126. El Kharroubi, A.; Piras, G.; Zensen, R.; Martin, M.A. Transcriptional activation of the integrated chromatin-associated human immunodeficiency virus type 1 promoter. Mol. Cell. Biol. 1998, 18, 2535-2544. [CrossRef] [PubMed]

127. Berger, S.L. Histone modifications in transcriptional regulation. Curr. Opin. Genet. Dev. 2002, 12, $142-148$. [CrossRef]

128. Adam, E.; Quivy, V.; Bex, F.; Chariot, A.; Collette, Y.; Vanhulle, C.; Schoonbroodt, S.; Goffin, V.; Nguyên, T.L.-A.; Gloire, G.; et al. Potentiation of tumor necrosis factor-induced NF- $\mathrm{B}$ activation by deacetylase inhibitors is associated with a delayed cytoplasmic reappearance of IкB $\alpha$. Mol. Cell. Biol. 2003, 23, 6200-6209. [CrossRef] [PubMed]

129. Bouchat, S.; Gatot, J.-S.; Kabeya, K.; Cardona, C.; Colin, L.; Herbein, G.; De Wit, S.; Clumeck, N.; Lambotte, O.; Rouzioux, C.; et al. Histone methyltransferase inhibitors induce HIV-1 recovery in resting CD4(+) T cells from HIV-1-infected HAART-treated patients. AIDS 2012, 26, 1473-1482. [CrossRef] [PubMed]

130. Kulkosky, J.; Culnan, D.M.; Roman, J.; Dornadula, G.; Schnell, M.; Boyd, M.R.; Pomerantz, R.J. Prostratin: Activation of latent HIV-1 expression suggests a potential inductive adjuvant therapy for HAART. Blood 2001, 98, 3006-3015. [CrossRef] [PubMed] 
131. Xing, S.; Bullen, C.K.; Shroff, N.S.; Shan, L.; Yang, H.-C.; Manucci, J.L.; Bhat, S.; Zhang, H.; Margolick, J.B.; Quinn, T.C.; et al. Disulfiram reactivates latent HIV-1 in a Bcl-2-transduced primary CD4+ T cell model without inducing global T cell activation. J. Virol. 2011, 85, 6060-6064. [CrossRef] [PubMed]

132. Doyon, G.; Zerbato, J.; Mellors, J.W.; Sluis-Cremer, N. Disulfiram reactivates latent HIV-1 expression through depletion of the phosphatase and tensin homolog. AIDS 2013, 27, F7-F11. [CrossRef] [PubMed]

133. Darcis, G.; Kula, A.; Bouchat, S.; Fujinaga, K.; Corazza, F.; Ait-Ammar, A.; Delacourt, N.; Melard, A.; Kabeya, K.; Vanhulle, C.; et al. An in-depth comparison of latency-reversing agent combinations in various in vitro and ex vivo HIV-1 latency models identified Bryostatin-1+JQ1 and Ingenol-B+JQ1 to potently reactivate viral gene expression. PLoS Pathog. 2015, 11, e1005063. [CrossRef] [PubMed]

134. International AIDS Society Scientific Working Group on HIV Cure; Deeks, S.G.; Autran, B.; Berkhout, B.; Benkirane, M.; Cairns, S.; Chomont, N.; Chun, T.-W.; Churchill, M.; Di Mascio, M.; et al. Towards an HIV cure: A global scientific strategy. Nat. Rev. Immunol. 2012, 12, 607-614. [CrossRef] [PubMed]

135. Bullen, C.K.; Laird, G.M.; Durand, C.M.; Siliciano, J.D.; Siliciano, R.F. New ex vivo approaches distinguish effective and ineffective single agents for reversing HIV-1 latency in vivo. Nat. Med. 2014, 20, 425-429. [CrossRef] [PubMed]

136. Chun, T.-W.; Moir, S.; Fauci, A.S. HIV reservoirs as obstacles and opportunities for an HIV cure. Nat. Immunol. 2015, 16, 584-589. [CrossRef] [PubMed]

137. Darcis, G.; Van Driessche, B.; Van Lint, C. HIV Latency: Should We Shock or Lock? Trends Immunol. 2017, 38, 217-228. [CrossRef] [PubMed]

138. Besnard, E.; Hakre, S.; Kampmann, M.; Lim, H.W.; Hosmane, N.N.; Martin, A.; Bassik, M.C.; Verschueren, E.; Battivelli, E.; Chan, J.; et al. The mTOR Complex Controls HIV Latency. Cell Host Microbe 2016, 20, 785-797. [CrossRef] [PubMed]

139. Kumar, A.; Abbas, W.; Colin, L.; Khan, K.A.; Bouchat, S.; Varin, A.; Larbi, A.; Gatot, J.-S.; Kabeya, K.; Vanhulle, C.; et al. Tuning of AKT-pathway by Nef and its blockade by protease inhibitors results in limited recovery in latently HIV infected T-cell line. Sci. Rep. 2016, 6, 24090. [CrossRef] [PubMed]

140. Kumar, A.; Abbas, W.; Bouchat, S.; Gatot, J.-S.; Pasquereau, S.; Kabeya, K.; Clumeck, N.; De Wit, S.; Van Lint, C.; Herbein, G. Limited HIV-1 reactivation in resting CD4(+) T cells from aviremic patients under protease inhibitors. Sci. Rep. 2016, 6, 38313. [CrossRef] [PubMed]

141. Vranckx, L.S.; Demeulemeester, J.; Saleh, S.; Boll, A.; Vansant, G.; Schrijvers, R.; Weydert, C.; Battivelli, E.; Verdin, E.; Cereseto, A.; et al. LEDGIN-mediated inhibition of integrase-LEDGF/p75 interaction reduces reactivation of residual latent HIV. EBioMedicine 2016, 8, 248-264. [CrossRef] [PubMed]

142. Messiaen, P.; Wensing, A.M.J.; Fun, A.; Nijhuis, M.; Brusselaers, N.; Vandekerckhove, L. Clinical use of HIV integrase inhibitors: A systematic review and meta-analysis. PLoS ONE 2013, 8, e52562. [CrossRef] [PubMed]

143. Withers, D.R.; Jaensson, E.; Gaspal, F.; McConnell, F.M.; Eksteen, B.; Anderson, G.; Agace, W.W.; Lane, P.J.L. The survival of memory CD4+ T cells within the gut lamina propria requires OX40 and CD30 signals. J. Immunol. 2009, 183, 5079-5084. [CrossRef] [PubMed]

144. Mahlknecht, U.; Deng, C.; Lu, M.C.; Greenough, T.C.; Sullivan, J.L.; O’Brien, W.A.; Herbein, G. Resistance to apoptosis in HIV-infected CD4+ T lymphocytes is mediated by macrophages: Role for Nef and immune activation in viral persistence. J. Immunol. 2000, 165, 6437-6446. [CrossRef] [PubMed]

(C) 2017 by the authors. Licensee MDPI, Basel, Switzerland. This article is an open access article distributed under the terms and conditions of the Creative Commons Attribution (CC BY) license (http:/ / creativecommons.org/licenses/by/4.0/). 